\title{
Chlorapatite Derived from Fish Scales
}

\author{
Luyara de Almeida Cavalcante ${ }^{1, * \mathbb{C}}$, Laís Sibaldo Ribeiro ${ }^{2}$, Mitsuo Lopes Takeno ${ }^{3}$, \\ Pedro Tupa Pandava Aum ${ }^{4}$ (D), Yanne Katiussy Pereira Gurgel Aum ${ }^{5}[$ and \\ Jean Carlos Silva Andrade ${ }^{6}$
}

1 Department of Chemistry, Environment and Food; Federal Institute of Education, Science and Technology of Amazonas, Manaus 69080900, Brazil

2 Department of Chemical Engineering, Federal University of Rio Grande do Norte, Natal 59078-970, Brazil; lais-sibaldo@hotmail.com

3 Federal Institute of Education, Science and Technology of Amazonas, Manaus 69080900, Brazil; mitsuolopestakeno@gmail.com

4 Faculty of Engineering, Federal University of Pará, Salinópolis, 68721000, Brazil; pedroaum@ufpa.br

5 Department of Chemical Engineering, Federal University of Amazonas, Manaus 69080900, Brazil; yanne@ufam.edu.br

6 Department of Materials Engineering, Federal University of Amazonas, Manaus 69080900, Brazil; jean.engmateriais@gmail.com

* Correspondence: luyara.cavalcante@ifam.edu.br; Tel.: +55-92-992626837

Received: 31 December 2019; Accepted: 26 February 2020; Published: 3 March 2020

\begin{abstract}
The present work demonstrates the production of chlorapatite (ClAp) through thermal decomposition of chemically treated fish scales, originating from an Amazon fish species (Arapaima gigas). The scales were treated with hydrochloric acid $(\mathrm{HCl})$ solution for deproteinization. Afterwards, the solution was neutralized by sodium hydroxide $(\mathrm{NaOH})$ treatment to obtain an apatite-rich slurry. The heat treatment was carried out at different temperatures including $600^{\circ} \mathrm{C}, 800^{\circ} \mathrm{C}$, and $1000^{\circ} \mathrm{C}$. The powders obtained were characterized through X-ray diffraction (XRD), Fourier transform infrared spectroscopy (FTIR), energy-dispersive X-ray spectroscopy (EDS), and scanning electron microscopy (SEM). The XRD analysis and FTIR spectra confirmed the incorporation of chlorine into the apatite structure. The FTIR results showed absorption bands relative to the $\mathrm{OH}^{-}, \mathrm{PO}_{4}{ }^{3-}$ functional groups which are a characteristic of chlorapatite. Moreover, the intensity of the $\mathrm{OH}-\mathrm{Cl}$ elongation could be observed. Chlorapatite $\mathrm{Ca}_{5}\left(\mathrm{PO}_{4}\right)_{3} \mathrm{Cl}, \mathrm{NaCl}$, and $\mathrm{NaCaPO}_{4}$ phases were identified, achieving up to $87.4 \mathrm{wt} \%$ for ClAp. The SEM observations show that with increasing temperature, the ClAp obtained consists of slightly larger, more crystalline grains. Furthermore, the grains ranged in size, between 1-5 $\mu \mathrm{m}$ and ClAp1000 sample recorded crystallinity of $84.27 \%$. ClAp and $\mathrm{NaCaPO}_{4}$ can be used in electronics as phosphor materials due to their luminescence and biomedical applications.
\end{abstract}

Keywords: Arapaima gigas; natural resource; phosphate; $\mathrm{NaCaPO}_{4}$; luminescence

\section{Introduction}

Calcium phosphate-based materials have been employed in a wide range of applications such as: biomedical [1-4]; wastewater treatment [5,6]; soil remediation [7]; foam [8]; display and solid state lightning [9]; and heterogeneous catalysis in chemical, material and industrial industries [10]. Calcium phosphate compounds can either be produced from inorganic precursors or from natural organic based materials. The use of wastes or by-products to obtain such compounds has attracted attention. Several studies have been developed using animal bones [11,12], fish scales [13], eggshells [14] and seashells [15]. 
Fish scales are formed by an organic component (collagen) and a mineral component (hydroxyapatite, HAp). HAp $\left(\mathrm{Ca}_{10}\left(\mathrm{PO}_{4}\right)_{6}(\mathrm{OH})_{2}\right)$ can be extracted from fish scales through a thermal process [16], chemical treatment [17], or both [18]. Nowadays, research has been conducted towards the modification of HAp by incorporating chemical species into the apatite structure in order to improve chemical and physical properties.

Kannan et al. [19] investigated the synthesis of chlorine substituted hydroxyapatites by aqueous precipitation. The substituted apatites show high thermal stability. Piccirillo et al. [20] carried out a combined washing-annealing process using fish scales to obtain chlorapatite $\left(\mathrm{Ca}_{10}\left(\mathrm{PO}_{4}\right)_{6} \mathrm{Cl}_{2}, \mathrm{ClAp}\right)$, whereby the replacement of hydroxyl groups occurred, replaced with chlorine, due to the presence of $\mathrm{NaCl}$ in sardine scales. ClAp can therefore be used in luminescent device applications [21] as well as in biomedicine to improve resorption, mechanical properties and bioactivity [22].

Recently, orthophosphates have been widely studied with findings suggesting they are efficient luminescent host materials due to their excellent thermal and charge stabilities [23-25]. $\mathrm{NaCaPO}_{4}$, an alkali-alkaline-earth orthophosphate compound, has been reported to be a host material for potential applications in white light emitting diodes ( $w$-LEDs), or, in other words, the next generation of solid-state light. $\mathrm{NaCaPO}_{4}$ exhibits strong UV absorption and higher physical and chemical stability [26]. Furthermore, the preparation of $\mathrm{NaCaPO}_{4}$ doped with rare-earth ions provides a strong emission intensity $[27,28]$.

In the work presented, fish scales from an Amazon fish species (Arapaima gigas) were used to produce phosphate-based compounds through a combined chemical-calcination process. To our knowledge, this is the first recorded time fish scales have been used as a source of HAp in a reaction with a chlorinating agent to produce ClAp. The materials obtained were characterized by several techniques (X-ray Diffraction, Fourier Transform Infrared Spectroscopy, Energy Dispersive X-ray Spectroscopy and Scanning Electron Microscopy) to determine their composition and microstructural features.

\section{Materials and Methods}

\subsection{Synthesis of Chlorapatite Powder from Fish Scale}

Fish scales (FS) from freshwater fish (Arapaima gigas) were obtained from a local market located in Manaus, Amazonas, Brazil.

Figure 1 shows the flow chart for the processing of fish scales to ClAp. The scales were isolated from the fish and washed thoroughly firstly with tap water and then with distilled water to ensure the removal of undesired debris. The adhering tissue was manually scraped. After washing, the scales were dried out at room temperature. Thereafter, the scales were soaked and stirred in $4 \mathrm{wt} \%$ hydrochloric acid $(\mathrm{HCl})$ solution for $15 \mathrm{~min}$ at room temperature to achieve deproteinization. Afterwards, the solution was neutralized by sodium hydroxide $(\mathrm{NaOH})$ treatment to obtain apatite-rich slurry and was subsequently filtered through the process of vacuum filtration. In order to produce biogenic ClAp powder, the resulting cake was subjected to calcination at $600^{\circ} \mathrm{C}, 800^{\circ} \mathrm{C}$ and $1000^{\circ} \mathrm{C}$, at a heating rate of $5^{\circ} \mathrm{C} / \mathrm{min}$ for $1 \mathrm{~h}$.

\subsection{Fish Scale and Chlorapatite Powder Characterizations}

Thermal behavior of the FS was analyzed from room temperature $\left(\sim 30^{\circ} \mathrm{C}\right)$ to $1000^{\circ} \mathrm{C}$ with a heating rate of $5^{\circ} \mathrm{C} / \mathrm{min}$ in a nitrogen atmosphere, using a simultaneous thermal analyzer (SDT Q600, TA Instruments, New Castle, USA. The functional groups in the fish scales and synthesized powders were identified using FTIR spectroscopy (Spectrum Shimadzu, model Prestige 21, Kyoto, Japan) in the range of $400-4000 \mathrm{~cm}^{-1}$. The XRD analysis of the synthesized powders was performed using Bruker D2 PHASER diffractometer (Bruker AXS, Karlsruhe, Germany) with $\mathrm{Cu} K \alpha 1$ radiation $(\lambda=15,406 \AA$ $30 \mathrm{kV}-10 \mathrm{~mA}$ ). The scanning was done between 10 and $60^{\circ}(2 \theta)$ with a $0.02^{\circ}$ step size at $60 \mathrm{~s}$ each step. The crystalline phase composition of powders was analyzed with XPert HighScore Plus Software (3.0, PANalytical B. V., Almelo, The Netherlands) and Inorganic Crystal Structure Database(ICSD). In 
order to obtain the lattice parameters, the structural refinement was performed by the Rietveld method using the General Structure Analysis System(GSAS). The fraction of crystallinity $\left(x_{c}\right)$ was estimated using Equation (1) [29].

$$
x_{c}=100 \times\left[1-\left(\frac{I_{300}-V_{112 / 300}}{I_{300}}\right)\right]
$$

where $\mathrm{I}_{300}$ is the intensity of 300 diffraction peak, $\mathrm{V}_{112 / 300}$ is the intensity of the hollow between 112 and 300 diffraction peaks of ClAp. The mean crystallite size $\mathrm{D}(\AA)$ was calculated using the Scherrer's equation [30].

$$
D(h k l)=\frac{0.91 \lambda}{\beta_{L} \cos \theta}
$$

where $\lambda$ is the copper wavelength, $\beta_{L}$ is the integral breadths of Lorentzian part in the pseudo-voight function of the diffraction simulated line, calculated according to Reference [31]. The morphology and the elemental compositions of scaffolds were identified using scanning electron microscopy (VEGA3TESCLAN ANALYTICS, Fuveau, França) equipped with an energy-dispersive X-ray (EDX) analyzer (Penta FET x-3 Si). The samples were coated with a thin conductive layer of gold and analyzed at 30 $\mathrm{kV}$ working voltage.

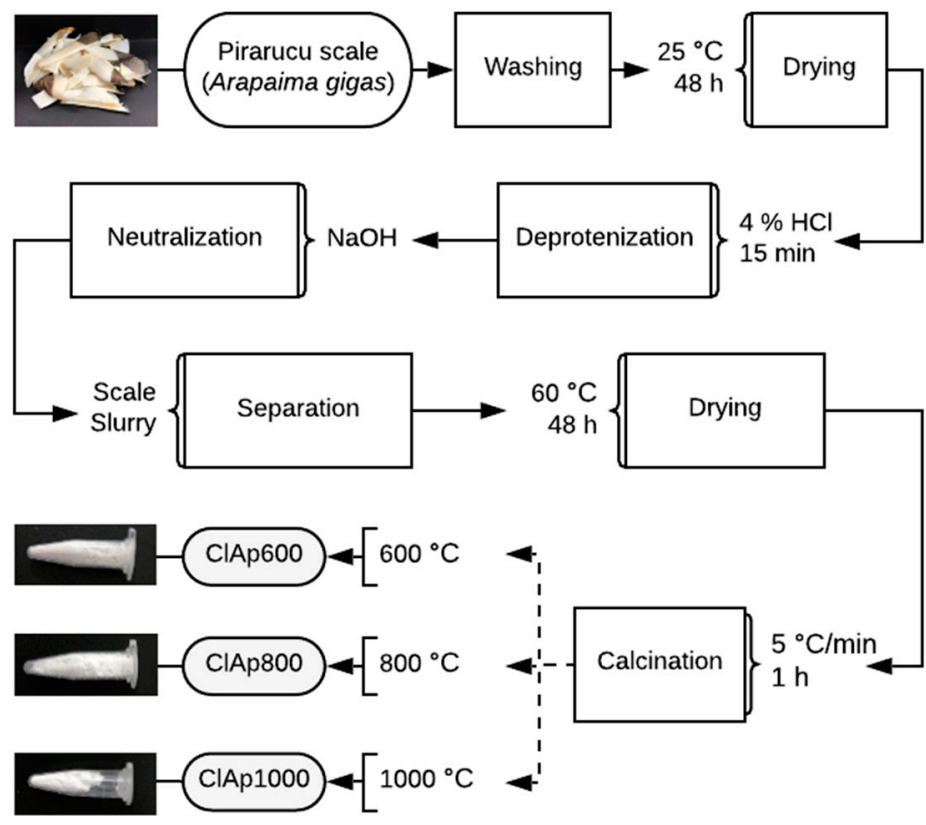

Figure 1. Flow chart for the processing of Arapaima gigas fish scales to chlorapatite (ClAp).

\section{Results and Discussion}

\subsection{Thermo-Gravimetric Analysis}

The thermogravimetric analysis was performed on the FS to evaluate thermal stability and weight loss, noting which calcination temperatures would be most appropriate for the material studied and what its yield would be.

Figure 2 shows the TGA curve and the first derivative (DTG curve; rate of change in mass) of the FS. Four different stages of weight loss can be observed in the temperature range $0-1000{ }^{\circ} \mathrm{C}$, amounting to a total weight loss greater than $60 \%$. The first stage of weight loss occurs in the temperature range of $25-210{ }^{\circ} \mathrm{C}$, reaching approximately $14.2 \%$. This can be understood to be related to the evaporation of the adsorbed water on the surface of the scales. The second stage, the DTG peak located at $323.2{ }^{\circ} \mathrm{C}$ refers to the degradation of organic compounds, principally collagen constituents. At this stage, the largest loss of mass occurs, at $26.2 \%$. The first and second stages are associated with the organic 
molecules present in the scales: amide I, amide II and amide III, which are characteristics of type I collagen, or, in other words, the mineralized collagen (collagen fiber cross-linking) characteristic of the fish scale used [32]. In addition to the possibility of trapped water in the porous structure of the scales, there may also be a small contribution caused by the release of crystallization water in hydroxyapatite [32,33].

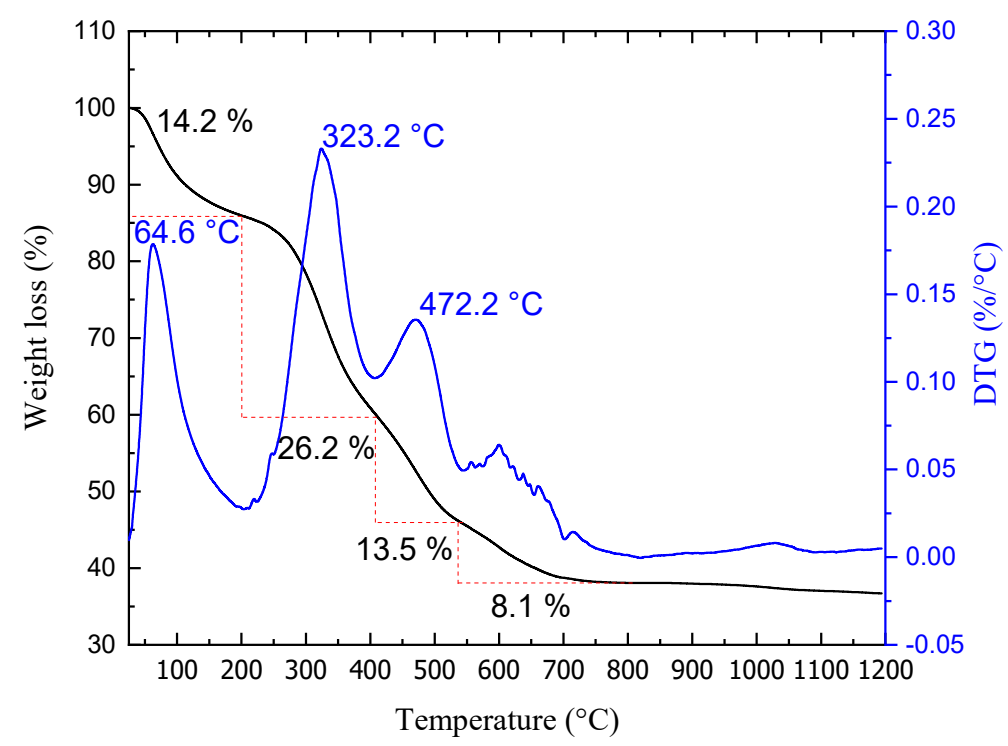

Figure 2. Thermogravimetric analysis.

The third step relates to protein loss from organic components such as guanines, representing a total weight loss of $13.5 \%$. The smallest loss of $8.1 \%$ can be seen between $540{ }^{\circ} \mathrm{C}$ and $820^{\circ} \mathrm{C}$. The latter may be associated with the decomposition of the inorganic phase, due to weight loss associated with the release of $\mathrm{Na}$ and $\mathrm{Mg}$ ions present in the scales of the species studied [34]; or, from decarbonization of calcium carbonate for formation of calcium oxide [35]. After $800^{\circ} \mathrm{C}$ there wasn't a significant change in weight recorded.

\subsection{X-Ray Diffraction}

Figure 3 shows XRD results for the chlorapatite samples synthesized at several temperatures including $600{ }^{\circ} \mathrm{C}, 800{ }^{\circ} \mathrm{C}$, and $1000{ }^{\circ} \mathrm{C}$. Calcium phosphate (V) chloride hydroxide, ICSD card $\mathrm{N}^{\circ} 1708$, formed at all calcination temperatures. The chlorapatite formed has a hexagonal crystal structure, space group $\mathrm{P} 63 / \mathrm{m}$ and chemical formula $\mathrm{H}_{1.37} \mathrm{Ca}_{9.71} \mathrm{Cl}_{0.8} \mathrm{O}_{25.37} \mathrm{P}_{6}$. The hexagonal phase formed at temperatures above $350{ }^{\circ} \mathrm{C}$. Below $350{ }^{\circ} \mathrm{C}$, its structure is monoclinic [36]. The other phase formed during chlorapatite synthesis was $\mathrm{NaCl}, \mathrm{ICSD}$ card $\mathrm{N}^{\circ} 60280$. The formation of this phase is justified according to the chemical Equation (3), since $\mathrm{HCl}$ was neutralized with $\mathrm{NaOH}$.

$$
\mathrm{HCl}+\mathrm{NaOH} \rightarrow \mathrm{NaCl}+\mathrm{H}_{2} \mathrm{O}
$$

The refinement shown in Figure $4 \mathrm{a}-\mathrm{c}$ records the phases of chlorapatite present in all samples: ClAp600; ClAp800; and ClAp1000. The XRD pattern of the chlorapatite calcined samples ( $1 \mathrm{~h}$ of overlap) was achieved through fitting according to the Rietveld refinement method method, followed by the deconvolution of the phases in order to obtain the percentage of calculated phases. Through analyses of the calculations of percentage by weight, it was confirmed that the ClAp1000 sample presented the highest percentage of chlorapatite, at approximately $87.4 \%$. wt. 


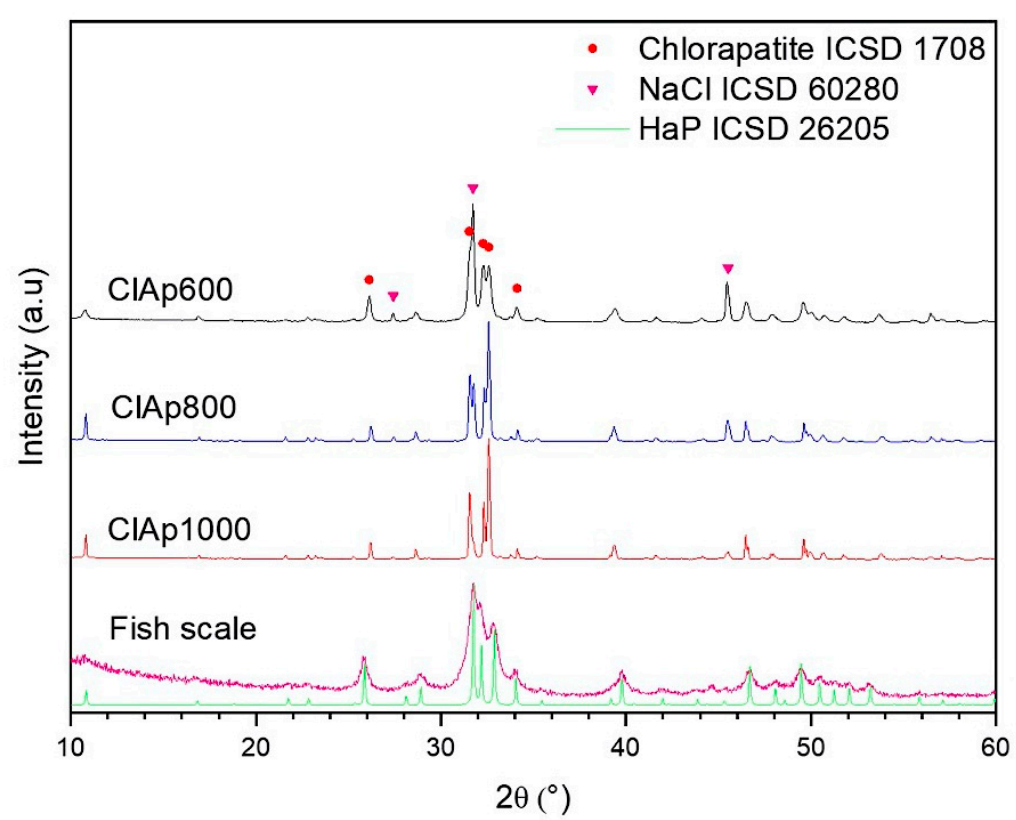

Figure 3. XRD patterns of the chlorapatite syntheses as a function of calcination temperature.
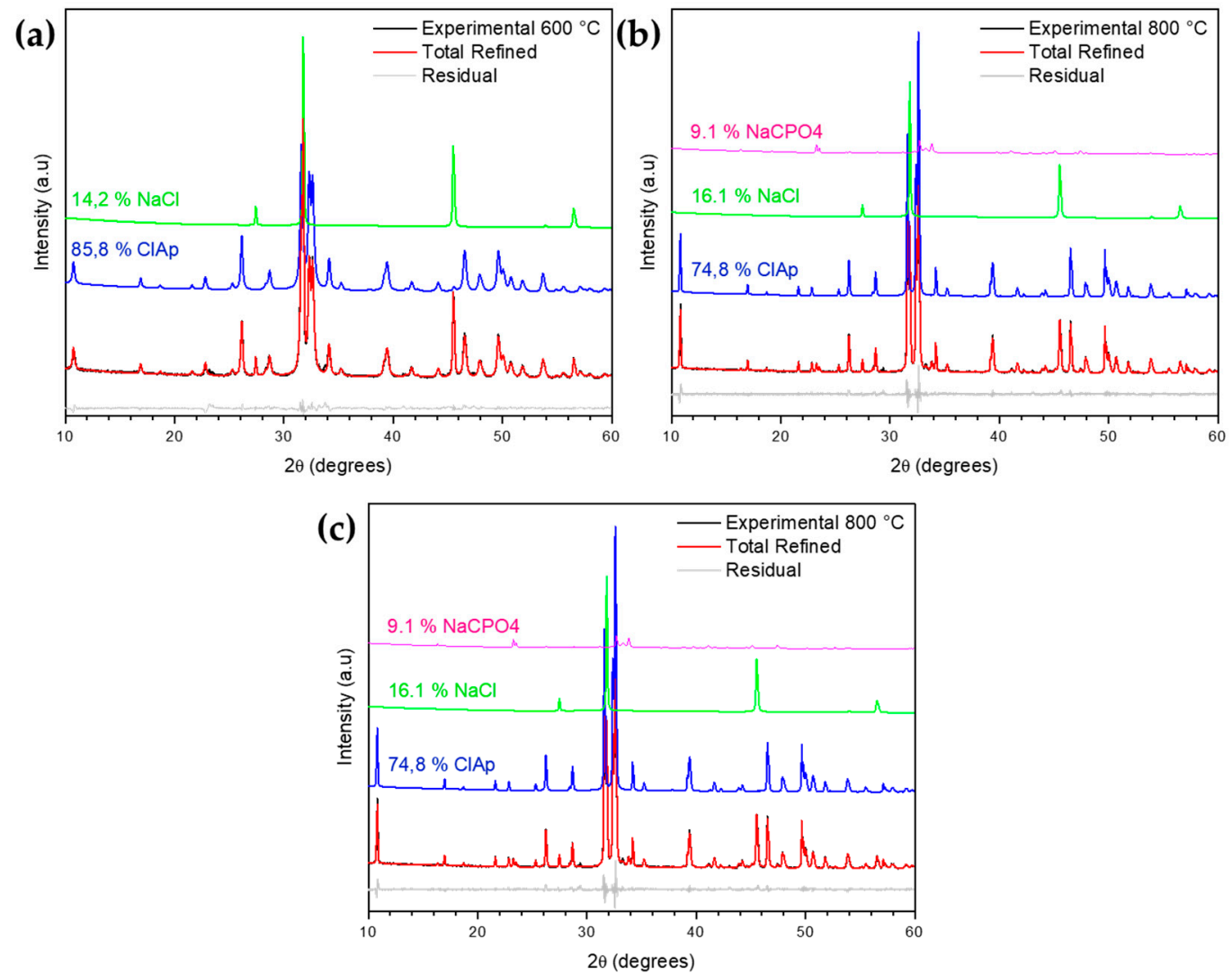

Figure 4. Experimental XRD pattern of the chlorapatite by the Rietveld method: (a) ClAp600; (b) ClAp800; and (c) ClAp1000.

Table 1 shows the percentage of phases found for all synthesized samples and provides the refinement and reliability parameters. The samples calcined at $800{ }^{\circ} \mathrm{C}$ and $1000{ }^{\circ} \mathrm{C}$ were observed to gain a new phase formation, namely, $\mathrm{NaCaPO}_{4}$ ICSD card $\mathrm{N}^{\circ} 5629$. It is suggested that in these calcination temperatures, the breakage occurs in apatite-linked chloride ions which, in turn, favors the binding of sodium ions. 
Table 1. Volume fraction of phases and crystallite size of ClAp powder derived from fish scales at different calcination temperatures.

\begin{tabular}{lccccccc}
\hline Sample & $\begin{array}{c}\text { Calcination } \\
\text { Temperature }\left({ }^{\circ} \mathbf{C}\right)\end{array}$ & $\begin{array}{c}\mathbf{C l A p} \\
\mathbf{( w t} \%)\end{array}$ & $\begin{array}{c}\mathbf{N a C l} \\
\mathbf{( w t} \%)\end{array}$ & $\begin{array}{c}\mathbf{N a C a P O}_{4} \\
\mathbf{( w t \% )}\end{array}$ & $\begin{array}{c}\text { Crystallite } \\
\text { Size (nm) }\end{array}$ & $\mathbf{R}_{\mathbf{w p}} \mathbf{( \% )}$ & $\boldsymbol{\chi}^{\mathbf{2}(\%)}$ \\
\hline ClAp600 & 600 & 85.8 & 14.2 & 0 & $28 \pm 5$ & 6.76 & 3.21 \\
ClAp800 & 800 & 74.8 & 16.1 & 9.1 & $78 \pm 12$ & 7.98 & 4.82 \\
ClAp1000 & 1000 & 87.4 & 6.1 & 6.5 & $65 \pm 8$ & 9.02 & 5.96 \\
\hline
\end{tabular}

The crystallite size for the chlorapatite phase was calculated for all the hkl plans using Equation (2) and can be found in Table $1[37,38]$. This the values are represented with their standard deviations. When comparing the crystallite sizes of the calcined samples, it can be observed that the ClAp600 sample has the smallest size, at around $28.6 \mathrm{~nm}$. The ClAp800 and ClAp1000 samples have a crystallite size of 78 (12) and 65 (8) respectively, showing a difference of about $13 \mathrm{~nm}$ between the two. This difference in crystallite size is within the margin of error that was calculated. Therefore, there was no significant variation in crystallite size for the ClAp800 and ClAp1000 samples. However, all samples had an average crystallite size of less than $78 \mathrm{~nm}$. The Ganjali et al. [39] study shows the effect of heat treatment on the structural characteristics of chlorapatite, with the authors noting an increase in the size of crystallite due to an increase in temperature.

The crystallinity of the samples was calculated using Equation (1). The values obtained were 33.66 wt. $\%, 66.77$ wt. $\%$ and 84.27 wt.\% for the samples ClAp00, ClAp800 and ClAp1000, respectively. Sharp peaks were observed at higher temperatures, owing to better crystallization. This increase in crystallinity values was also observed in the work of Piccirillo et al. [20] and Paul et al. [16], where hydroxyapatite was calcined at various temperatures.

\subsection{FTIR Spectra Analysis}

The formation of apatite phase in FS-derived ClAp powder was further confirmed by FTIR analysis. Figure $5 \mathrm{a}, \mathrm{b}$ shows the comparative FTIR spectra of the chemically treated FS-derived powder calcined at $600{ }^{\circ} \mathrm{C}, 800{ }^{\circ} \mathrm{C}$, and $1000^{\circ} \mathrm{C}$. Figure 5 a shows the spectra normalized which promotes an identification comparison the identification of the bands, while Figure $5 \mathrm{~b}$ shows the spectra with a real dimension of the $y$-axis which promotes a comparison in relation to peak intensities.
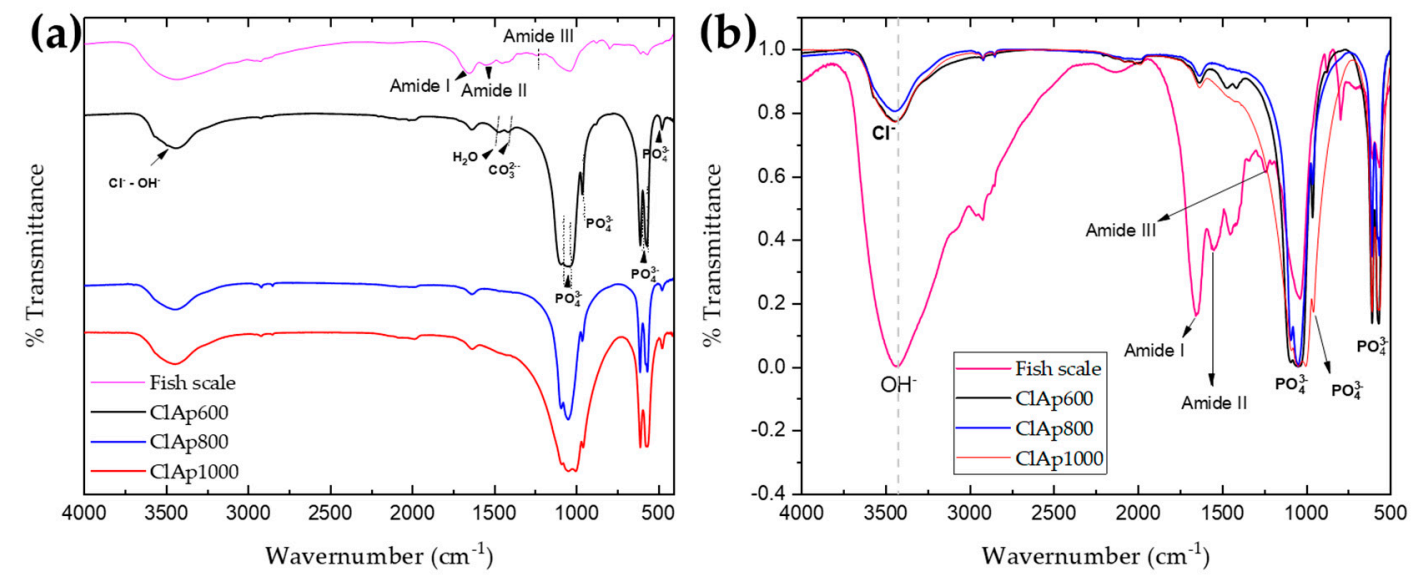

Figure 5. FTIR spectrum of calcined powders and FS: (a) Normalized spectrums; (b) Spectrum with real y-axis.

In the FTIR spectra, the bands $1654 \mathrm{~cm}^{-1}, 1546 \mathrm{~cm}^{-1}$ and $1242 \mathrm{~cm}^{-1}$ were assigned to amide I, II and III of collagen [34]. The peak $1654 \mathrm{~cm}^{-1}$ is associated with the $\mathrm{C}=\mathrm{O}$ stretching vibrations of the amide I protein; the peak $1546 \mathrm{~cm}^{-1}$ is associated with bending and stretching vibrations, whereby the 
$\mathrm{N}-\mathrm{H}$ and C-N correspond to amide II; the peak $1242 \mathrm{~cm}^{-1}$ is associated with bending vibrations that also corresponds to amide II [16]. The inorganic components are associated with calcium phosphate formation which in turn is associated with hydroxyapatite formation, which are bands for the phosphate (562-602 $\mathrm{cm}^{-1}$ and $\left.1034 \mathrm{~cm}^{-1}\right)$ and carbonate anions $\left(793 \mathrm{~cm}^{-1}, 873 \mathrm{~cm}^{-1}\right.$ and $\left.1449 \mathrm{~cm}^{-1}\right)$ groups [40,41].

Hence, the infrared spectra coincide with the results obtained from the X-ray patterns, with no significant changes or distortions observed in the position of functional groups and thus accounting for the formation of solid solutions in chlorine substituted apatite's. The band of $2920 \mathrm{~cm}^{-1}$ refers to the stretching vibration of the $\mathrm{C}-\mathrm{H}$ groups. The carbon chains of the monomers chemically constitute the scale in the peak $1636 \mathrm{~cm}^{-1}$ where carbonates formation can be observed [41]. The fundamental vibrational modes of $\left(\mathrm{PO}_{4}{ }^{3-}\right)$ tetrahedra of apatite phase are witnessed in all powders in the regions of $1088 \mathrm{~cm}^{-1}, 1046 \mathrm{~cm}^{-1}$ and $959 \mathrm{~cm}^{-1}$. whereby asymmetric deformation is identified. At bands $605 \mathrm{~cm}^{-1}$, $565 \mathrm{~cm}^{-1}$ and $473 \mathrm{~cm}^{-1}$, the symmetric stretching modes can be seen [42,43]. These findings are shown in Table 2.

Table 2. Infrared absorption bands at ClAp600, 800, and 1000.

\begin{tabular}{ccc}
\hline Absorption Region $\mathbf{( c m}^{-\mathbf{1}} \mathbf{)}$ & Intensity & Designation \\
\hline 3400 & Strong & stretch $\mathrm{OH}-\mathrm{Cl}$ \\
2920 & Weak & group stretching $\mathrm{C}-\mathrm{H}$ \\
1636 & Medium & $\mathrm{v}^{1}$ symmetric stretching $\mathrm{CO}_{3}{ }^{2-}$ \\
1088,1046 , and 959 & Strong & $\mathrm{r}^{3}$ anti-symmetric stretch $\mathrm{PO}_{4}{ }^{3-}$ \\
605,565 , and 473 & Strong & $\mathrm{v}^{1}$ symmetric stretching $\mathrm{PO}_{4}{ }^{3-}$ \\
\hline
\end{tabular}

According to Figure 5 (b), when comparing the spectra intensities of the FS sample in relation to the calcined samples there is a decrease in the intensity of the stretching vibrator observed at 3430 $\mathrm{cm}^{-1}$ and a reduction in the relative intensity in the band absorption of $\mathrm{OH}-$, which corresponds to the formation of ClAp. The disappearance of the bands corresponding to collagen can also be noted. As the calcination temperature increases, especially in the ClAp1000 sample, there is an enlargement of phosphate bands $\left(1034 \mathrm{~cm}^{-1}\right)$ and a loss of carbon chains $\left(2920 \mathrm{~cm}^{-1}\right.$ and $\left.1636 \mathrm{~cm}^{-1}\right)$. This may indicate an approximation of the mineral state of the bone and, according to recent studies, could be indicative of good osteointegration and biocompatibility [44].

\subsection{Powder Morphology}

Figure 6a-c shows the micrography in the samples of ClAp. The extracted ClAp shows particles with different morphologies.

In Figure 6 the SEM images show that with the increase in the calcination temperature there is an increase in chlorapatite crystals. In Figure 6a shows the ClAp600 sample, where a large number of agglomerated and ultrafine ClAp particles can be observed. In Figure $6 b$, the ClAp800 sample has three visible structures, one in the shape of a stick, one agglomerated and the other polygonized. On the other hand, in Figure 6c the ClAp1000 sample has a rather uniform morphology and polygonal structure. Particle size is not necessarily the crystallite size, for example, in the formation of hard agglomerates [45]. The García-Tuñón et al. [46] study shows the synthesis of ClAp with different morphologies using the molten salt method with $\mathrm{CaCl}_{2}$ as a flux.

From the SEM observations, it can be noted that the ClAp obtained consists of grains with sizes smaller than $1 \mu \mathrm{m}$ in the ClAp600 sample and sizes between 1-5 $\mu \mathrm{m}$ in the ClAp1000 sample, becoming more crystalline with increasing temperature. This same analysis shows the geometrization of the particles becoming more regular, increasing the contact area between the grains, which leads to an increase of mass transfer pathways related to volumetric diffusion phenomena [47]. This may favor the transport of cells in the microstructure of the material, such as in contact with body fluid. 


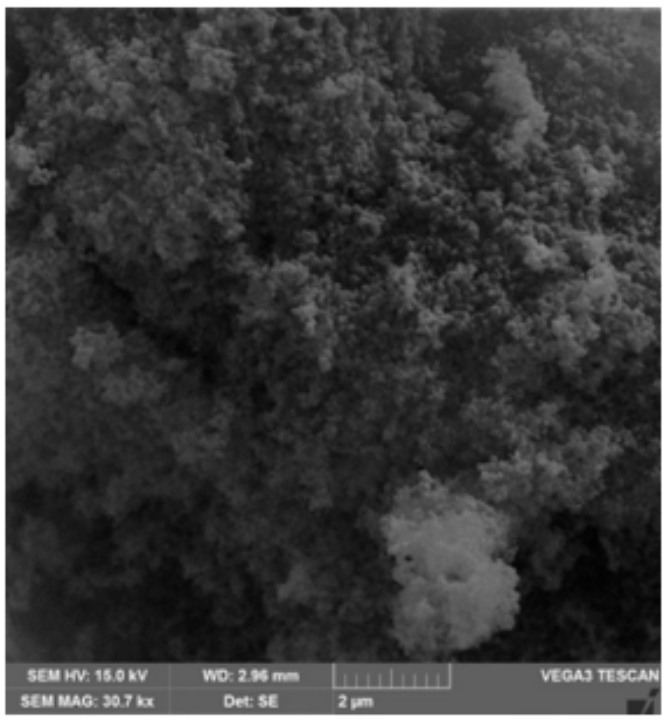

(a)

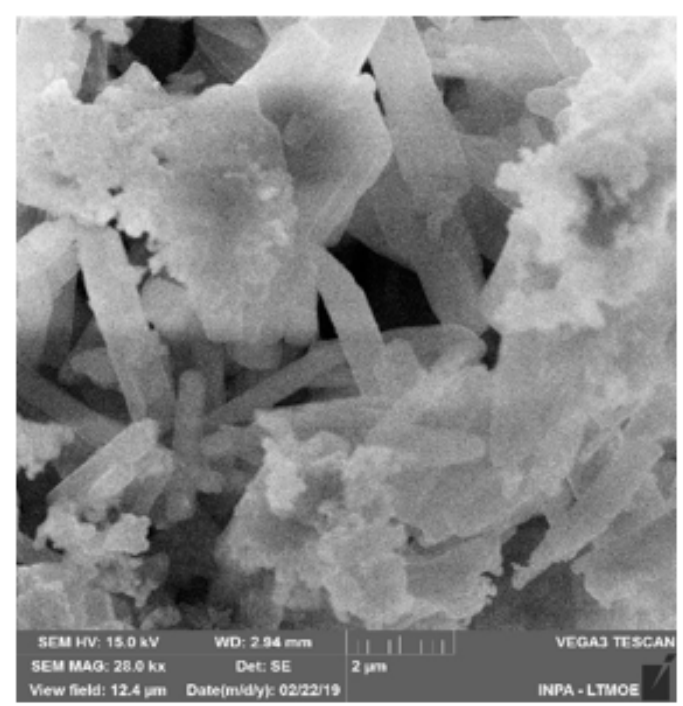

(b)

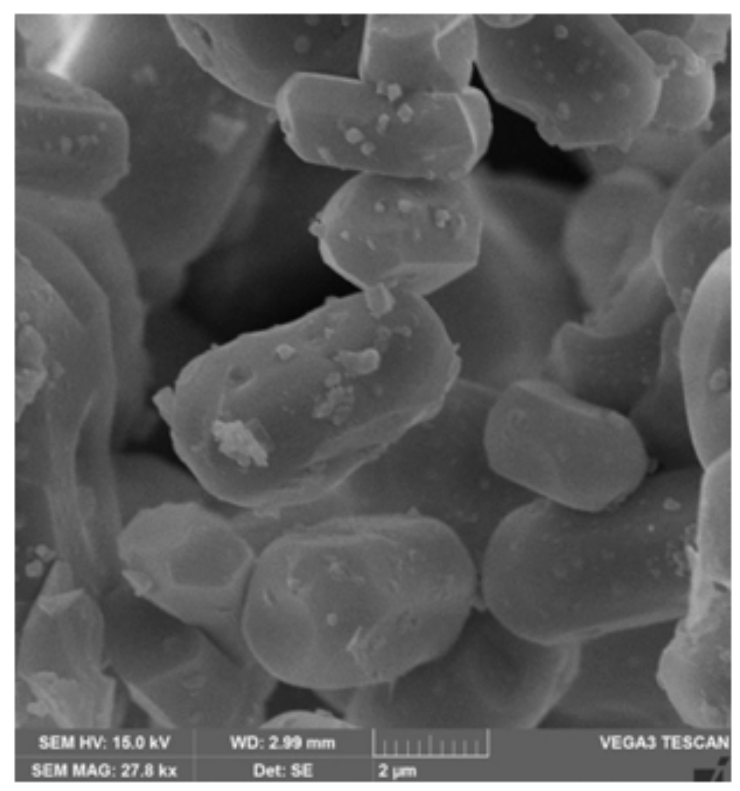

(c)

Figure 6. SEM images of chlorapatite calcined at different temperature: (a) $600{ }^{\circ} \mathrm{C}(\mathrm{ClAp} 600) ;(\mathbf{b}) 800^{\circ} \mathrm{C}$ (ClAp800); and (c) $1000^{\circ} \mathrm{C}(\mathrm{ClAp} 1000)$.

Presented in Table 3, the EDS analysis confirms the presence of $\mathrm{Ca}, \mathrm{P}$ and $\mathrm{Cl}$. The quantitative analysis revealed that the composition ratio of calcium and phosphorous in the sample is 1.44 , which is smaller than the stoichiometric ratio of $\mathrm{Ca}$ and $\mathrm{P}(1.67)$ in the pure HAp powder. This corroborates previous research, proving that the $\mathrm{ClAp}$ obtained is more soluble than $\mathrm{HAp}$. Pure $\mathrm{ClAp}, \mathrm{Ca}_{10}\left(\mathrm{PO}_{4}\right)_{6} \mathrm{Cl}_{2}$, has the $\mathrm{Ca} / \mathrm{Cl}$ ratio of 5 [48]. The sample $\mathrm{ClAp} 1000$ obtained the best $\mathrm{Ca} / \mathrm{Cl}$ ratio, which suggests it was due to the increase in ClAp phase in this sample, as shown in the XRD and FTIR results, as well as the reduction in carbonates with the temperature increase. 
Table 3. EDS analysis of powder samples.

\begin{tabular}{ccccccccc}
\hline \multirow{2}{*}{ Sample } & \multicolumn{9}{c}{ Atomic \% } & \multirow{2}{*}{ Ca/P } & Ca/Cl \\
\cline { 2 - 7 } & $\mathbf{O}$ & $\mathbf{C a}$ & $\mathbf{P}$ & $\mathbf{C}$ & $\mathbf{C l}$ & $\mathbf{N a}$ & & \\
\hline ClAp600 & $39.14 \pm 0.83$ & $5.20 \pm 0.23$ & $3.81 \pm 0.18$ & $48.00 \pm 1.2$ & $1.61 \pm 0.14$ & $2.19 \pm 0.07$ & 1.36 & 3.22 \\
ClAp800 & $51.96 \pm 8.02$ & $8.62 \pm 2.28$ & $6.00 \pm 1.69$ & $26.26 \pm 10.9$ & $3.23 \pm 0.55$ & $3.95 \pm 0.54$ & 1.44 & 2.67 \\
ClAp1000 & $64.26 \pm 3.34$ & $14.00 \pm 0.90$ & $9.93 \pm 0.44$ & $2.90 \pm 3.87$ & $3.65 \pm 1.18$ & $4.98 \pm 1.12$ & 1.41 & 3.84 \\
\hline
\end{tabular}

It is worth mentioning that MEV / EDS are analyzes made on the surface of the sample, having no relation to the size of crystallites, but rather to the size of the particles/grains, which in this case are related to calcination temperatures. Therefore, the particle size does not significantly change its stoichiometric structure [45,49].

\section{Conclusions}

In the presented work, chlorapatite was synthesized by a simple thermal decomposition of chemically treated fish scales. In all of the samples, XDR analysis identified ClAp as the main component (87.4 $\mathrm{wt} \%)$, whilst two of the samples had $\mathrm{NaCaPO}_{4}$ as the secondary component and all had $\mathrm{NaCl}$ as the third component. The degree of crystallinity and the particle size of fish scales derived ClAp increased with increasing calcination temperature. All samples recorded crystallite sizes of less than $78 \mathrm{~nm}$. FTIR results show the incorporation of $\mathrm{Cl}$ in channel sites of the apatite. SEM has confirmed a non-homogeneous growth of particles with temperature, showing more uniform particles, with grains ranging in sizes between 1-5 $\mu \mathrm{m}$ in the ClAp1000 sample. EDS analysis has confirmed a $\mathrm{Ca} / \mathrm{Cl}$ ratio of 3.84 close to the stoichiometric $\mathrm{ClAp}$ ratio. $\mathrm{ClAp}$ and $\mathrm{NaCaPO}_{4}$ can be used as phosphor materials in electronics on account of to their potential for luminescence. Further, chlorine-substituted HAp is a compound with an interesting potential in biomedical applications due to the fact that the presence of chlorine in the HAp lattice may improve its resorption as well as mechanical properties [22].

Author Contributions: L.d.A.C. performed the experiments, analyzed the data, and wrote the initial draft of the manuscript. L.S.R. and P.T.P.A. provided support with experiments. M.L.T. provided support with experiments, data analysis, and manuscript writing. Y.K.P.G.A. proposed the topic of this study and supervised the research including manuscript writing. J.C.S.A. supervised and administrated the research project and was responsible for funding acquisition. All authors have read and agreed to the published version of the manuscript.

Funding: This research was funded by FAPEAM and CT-INFRA/MCTI/CNPq.

Acknowledgments: The authors acknowledge the experimental support of LABMAT/UFAM, Central Analytical da UEA-EST, Laboratory Thematic of Optical and Electronic Microscopy LTMOE/COPES/INPA. This study was financed in part by the Coordenação de Aperfeiçoamento de Pessoal de Nível Superior - Brasil (CAPES) - Finance Code 001.

Conflicts of Interest: The authors declare no conflict of interest.

\section{References}

1. Denry, I.; Kuhn, L.T. Design and characterization of calcium phosphate ceramic scaffolds for bone tissue engineering. Dent. Mater. 2016, 32, 43-53. [CrossRef] [PubMed]

2. Dey, S.; Das, M.; Balla, V.K. Effect of hydroxyapatite particle size, morphology and crystallinity on proliferation of colon cancer HCT116 cells. Mater. Sci. Eng. C 2014, 39, 336-339.

3. Oesterle, A.; Boehm, A.; Müller, F. Photoluminescent $\mathrm{Eu}^{3+}$-doped calcium phosphate bone cement and its mechanical properties. Materials 2018, 11, 1610.

4. Alhamdi, J.; Jacobs, E.; Gronowicz, G.; Benkirane-Jessel, N.; Hurley, M.; Kuhn, L. Cell type influences local delivery of biomolecules from a bioinspired apatite drug delivery system. Materials 2018, 11, 1703. [CrossRef]

5. Murgolo, S.; Moreira, I.; Piccirillo, C.; Castro, P.; Ventrella, G.; Cocozza, C.; Mascolo, G. Photocatalytic degradation of diclofenac by hydroxyapatite- $\mathrm{TiO}_{2}$ composite material: Identification of transformation products and assessment of Toxicity. Materials 2018, 11, 1779. [CrossRef]

6. Iconaru, S.; Motelica-Heino, M.; Guegan, R.; Beuran, M.; Costescu, A.; Predoi, D. Adsorption of Pb (II) ions onto hydroxyapatite nanopowders in aqueous solutions. Materials 2018, 11, 2204. 
7. Nzihou, A.; Sharrock, P. Role of phosphate in the remediation and reuse of heavy metal polluted wastes and sites. Waste Biomass Valor. 2010, 1, 163-174. [CrossRef]

8. Chiarathanakrit, C.; Riyajan, S.A.; Kaewtatip, K. Transforming fish scale waste into an efficient filler for starch foam. Carbohydr. Polym. 2018, 188, 48-53. [CrossRef]

9. Yang, R.Y.; Peng, Y.M.; Lai, H.L.; Su, Y.K.; Chang, S.J. The optimum sintering condition for $\mathrm{KSrPO}_{4}: \mathrm{Eu}^{3+}$ phosphors applied in WLEDs. Ceram. Int. 2017, 43, S682-S687. [CrossRef]

10. Fihri, A.; Len, C.; Varma, R.S.; Solhy, A. Hydroxyapatite: A review of syntheses, structure and applications in heterogeneous catalysis. Coord. Chem. Rev. 2017, 347, 48-76. [CrossRef]

11. Sunil, B.R.; Jagannatham, M. Producing hydroxyapatite from fish bones by heat treatment. Mater. Lett. 2016, 185, 411-414. [CrossRef]

12. Ofudje, E.A.; Rajendran, A.; Adeogun, A.I.; Idowu, M.A.; Kareem, S.O.; Pattanayak, D.K. Synthesis of organic derived hydroxyapatite scaffold from pig bone waste for tissue engineering applications. Adv. Powder Technol. 2018, 29, 1-8. [CrossRef]

13. Panda, N.N.; Pramanik, K.; Sukla, L.B. Extraction and characterization of biocompatible hydroxyapatite from fresh water fish scales for tissue engineering scaffold. Bioprocess Biosyst. Eng. 2014, 37, 433-440. [CrossRef] [PubMed]

14. Wu, S.-C.; Tsou, H.K.; Hsu, H.C.; Hsu, S.K.; Liou, S.P.; Ho, W.F. A hydrothermal synthesis of eggshell and fruit waste extract to produce nanosized hydroxyapatite. Ceram. Int. 2013, 39, 8183-8188. [CrossRef]

15. Dhanaraj, K.; Suresh, G. Conversion of waste sea shell (Anadara granosa) into valuable nanohydroxyapatite (nHAp) for biomedical applications. Vacuum 2018, 152, 222-230. [CrossRef]

16. Paul, S.; Pal, A.; Choudhury, A.R.; Bodhak, S.; Balla, V.K.; Sinha, A.; Das, M. Effect of trace elements on the sintering effect of fish scale derived hydroxyapatite and its bioactivity. Ceram. Int. 2017, 43, 15678-15684. [CrossRef]

17. Pon-On, W.; Suntornsaratoon, P.; Charoenphandhu, N.; Thongbunchoo, J.; Krishnamra, N.; Tang, I.M. Synthesis and investigations of mineral ions-loaded apatite from fish scale and PLA/chitosan composite for bone scaffolds. Mater. Lett. 2018, 221, 143-146. [CrossRef]

18. Prasad, A.; Bhasney, S.; Katiyar, V.; Ravi Sankar, M. Biowastes processed hydroxyapatite filled poly (lactic acid) bio-composite for open reduction internal fixation of small bones. Mater. Today: Proc. 2017, 4, 10153-10157. [CrossRef]

19. Kannan, S.; Rocha, J.H.G.; Ferreira, J.M.F. Synthesis of hydroxy-chlorapatites solid solutions. Mater. Lett. 2006, 60, 864-868. [CrossRef]

20. Piccirillo, C.; Pullar, R.C.; Tobaldi, D.M.L.; Castro, P.M.; Pintado, M.E. Hydroxyapatite and chloroapatite derived from sardine by-products. Ceram. Int. 2014, 40, 13231-13240. [CrossRef]

21. Wang, W.N.; Kaihatsu, Y.; Iskandar, F.; Okuyama, K. Highly Luminous Hollow Chloroapatite Phosphors Formed by a Template-Free Aerosol Route for Solid-State Lighting. Chem. Mater. 2009, 21, 4685-4691. [CrossRef]

22. Demnati, I.; Grossin, D.; Marsan, O.; Bertrand, G.; Collonges, G.; Combes, C.; Parco, M.; Braceras, I.; Alexis, J.; Balcaen, Y.; et al. Comparison of physical-chemical and mechanical properties of chlorapatite and hydroxyapatite plasma sprayed coatings. Open Biomed. Eng. J. 2015, 9, 42-55. [CrossRef] [PubMed]

23. Yang, Z.; Yang, G.; Wang, S.; Tian, J.; Li, X.; Guo, Q.; Fu, G. A novel green-emitting phosphor $\mathrm{NaCaPO}_{4}$ : $\mathrm{Eu}^{2+}$ for white LEDs. Mater. Lett. 2008, 62, 1884-1886. [CrossRef]

24. Shi, L.; Huang, Y.; Seo, H.J. Emission Red Shift and Unusual Band Narrowing of $\mathrm{Mn}^{2+}$ in $\mathrm{NaCaPO}_{4}$ Phosphor. J. Phys. Chem. A 2010, 114, 6927-6934. [CrossRef]

25. Hingwe, V.S.; Bajaj, N.S.; Omanwar, S.K. Eu ${ }^{3+}$ doped N-UV emitting $\mathrm{LiSrPO}_{4}$ phosphor for W-LED application. Optik 2017, 130, 149-153. [CrossRef]

26. Ratnam, B.V.; Sahu, M.K.; Vishwakarma, A.K.; Jha, K.; Woo, H.J.; Jang, K.; Jayasimhadri, M. Optimization of synthesis technique and luminescent properties in $\mathrm{Eu}^{3+}$-activated $\mathrm{NaCaPO}_{4}$ phosphor for solid state lighting applications. J. Lumin. 2017, 185, 99-105. [CrossRef]

27. Shinde, K.N.; Dhoble, S.J.; Kumar, A. Photoluminescence studies of $\mathrm{NaCaPO}_{4}: \mathrm{RE}\left(\mathrm{RE}=\mathrm{Dy}^{3+}, \mathrm{Mn}^{2+}\right.$ or $\mathrm{Gd}^{3+}$ ). Phys. B Condens. Matter 2011, 406, 94-99. [CrossRef]

28. Shinde, K.; Dhoble, S.; Kumar, A. Combustion synthesis of $\mathrm{Ce}^{3+}, \mathrm{Eu}^{3+}$ and $\mathrm{Dy}^{3+}$ activated $\mathrm{NaCaPO}_{4}$ phosphors. J. Rare Earth. 2011, 29, 527-535. [CrossRef] 
29. Pal, A.; Paul, S.; Choudhury, A.R.; Balla, V.K.; Das, M.; Sinha, A. Synthesis of hydroxyapatite from Lates calcarifer fish bone for biomedical applications. Mater. Lett. 2017, 203, 89-92. [CrossRef]

30. Cullity, B.D. Elements of X-ray Diffraction; Addison-Wesley Publishing: Boston, MA, USA, 1956.

31. Takeno, M.L.; da Silva, G.A.; Trichês, D.M.; Ghosh, A.; de Souza, S.M. Structural studies of the layered SnSe produced by mechanical alloying and melting technique. J. Alloy. Compd. 2018, 735, 489-495. [CrossRef]

32. Pati, F.; Adhikari, B.; Dhara, S. Isolation and characterization of fish scale collagen of higher thermal stability. Bioresour. Technol. 2010, 101, 3737-3742. [CrossRef] [PubMed]

33. Thomas, V.; Dean, D.R.; Jose, M.V.; Mathew, B.; Chowdhury, S.; Vohra, Y.K. Nanostructured biocomposite scaffolds based on collagen coelectrospun with nanohydroxyapatite. Biomacromolecules 2007, 8, 631-637. [CrossRef]

34. Lin, Y.S.; Wei, C.T.; Olevsky, E.A.; Meyers, M.A. Mechanical properties and the laminate structure of Arapaima gigas scales. J. Mech. Behav. Biomed. Mater. 2011, 4, 1145-1156. [CrossRef] [PubMed]

35. Muhammad, N.; Gao, Y.; Iqbal, F.; Ahmad, P.; Ge, R.; Nishan, U.; Rahim, A.; Gonfa, G.; Ullah, Z. Extraction of biocompatible hydroxyapatite from fish scales using novel approach of ionic liquid pretreatment. Sep. Purif. Technol. 2016, 161, 129-135. [CrossRef]

36. Elliot, J.C. Structure and Chemistry of the Apatites and Other Calcium Orthophosphates; Elsevier: Amsterdam, The Netherlands, 1994.

37. Rietveld, H.M. A profile refinement method for nuclear and magnetic structures. J Appl Crystallogr 1969, 2, 65-71. [CrossRef]

38. Stephens, P.W. Phenomenological model of anisotropic peak broadening in powder diffraction. J Appl Crystallogr 1999, 32, 281-289. [CrossRef]

39. Ganjali, M.; Pourhashem, S.; Mozafari, M. The effect of heat-treatment on the structural characteristics of nanocrystalline chlorapatite particles synthesized via an in situ wet-chemical route. Ceram. Int. 2015, 41, 13100-13104. [CrossRef]

40. Sathiskumar, S.; Vanaraj, S.; Sabarinathan, D.; Bharath, S.; Sivarasan, G.; Arulmani, S.; Preethi, K.; Ponnusamy, V.K. Green synthesis of biocompatible nanostructured hydroxyapatite from Cirrhinus mrigala fish scale-A biowaste to biomaterial. Ceram. Int. 2019, 45, 7804-7810. [CrossRef]

41. Pandele, A.M.; Constantinescu, A.; Radu, I.C.; Miculescu, F.; Ioan Voicu, S.; Ciocan, L.T. Synthesis and characterization of pla-micro-structured hydroxyapatite composite films. Materials 2020, 13, 274. [CrossRef]

42. Sofronia, A.M.; Baies, R.; Anghel, E.M.; Marinescu, C.A.; Tanasescu, S. Thermal and structural characterization of synthetic and natural nanocrystalline hydroxyapatite. Mater. Sci. Eng. C 2014, 43, 153-163. [CrossRef]

43. Koutsopoulos, S. Synthesis and characterization of hydroxyapatite crystals: A review study on the analytical methods. J. Biomed. Mater. Res. 2002, 62, 600-612. [CrossRef] [PubMed]

44. Yamamura, H.; da Silva, V.H.P.; Ruiz, P.L.M.; Ussui, V.; Lazar, D.R.R.; Renno, A.C.M.; Ribeiro, D.A. Physico-chemical characterization and biocompatibility of hydroxyapatite derived from fish waste. J. Mech. Behav. Biomed. Mater. 2018, 80, 137-142. [CrossRef] [PubMed]

45. Ruys, A. Processing, structure, and properties of alumina ceramics. In Alumina Ceramics: Biomedical and Clinical Applications, 4th ed.; Woodhead Publishing: Duxford, UK, 2018; pp. 71-121.

46. García-Tuñón, E.; Couceiro, R.; Franco, J.; Saiz, E.; Guitián, F. Synthesis and characterisation of large chlorapatite single-crystals with controlled morphology and surface roughness. J Mater Sci: Mater. Med. 2012, 23, 2471-2482. [CrossRef] [PubMed]

47. Thomas, S.; Balakrishnan, P.; Sreekala, M.S. Fundamental Biomaterials: Ceramics; Woodhead Publishing: Duxford, UK, 2018.

48. Ito, A.; Otsuka, Y.; Takeuchi, M.; Tanaka, H. Mechanochemical synthesis of chloroapatite and its characterization by powder X-ray diffractometory and attenuated total reflection-infrared spectroscopy. Colloid. Polym. Sci. 2017, 295, 2011-2018. [CrossRef]

49. Widatallah, H.M.; Johnson, C.; Gismelseed, A.M.; Al-Omari, I.A.; Stewart, S.J.; Al-Harthi, S.H.; Thomas, S.; Sitepu, H. Structural and magnetic studies of nanocrystalline $\mathrm{Mg}$-doped $\mathrm{Li}_{0.5} \mathrm{Fe}_{2.5} \mathrm{O}_{4}$ particles prepared by mechanical milling. J. Phys. D Appl. Phys. 2008, 41, 165006. [CrossRef]

(C) 2020 by the authors. Licensee MDPI, Basel, Switzerland. This article is an open access article distributed under the terms and conditions of the Creative Commons Attribution (CC BY) license (http://creativecommons.org/licenses/by/4.0/). 